\title{
Four Neonatal Complex Ovarian Cyst Cases with Uncommon Complications
}

\section{Nadir Komplikasyonlarla Giden Dört Yenidoğan Kompleks Over Kisti Olguları}

\author{
Alkım Öden Akman, Nazile Ertürk*, Sibel Altınbaş**, Mithat Haliloğlu***, Ahmet Yağmur Baş**** \\ Ankara Child Health and Diseases Hematology Oncology Training and Research Hospital, Clinic of Child Health and Diseases, Ankara, Turkey \\ `Etlik Zübeyde Hanım Gynecology Training and Research Hospital, Clinic of Pediatric Surgery, Ankara, Turkey \\ **Etlik Zübeyde Hanım Gynecology Training and Research Hospital, Clinic of Gynecology and Obstetrics, Ankara, Turkey \\ ***Hacettepe University Faculty of Medicine, Department of Radiology, Ankara, Turkey \\ ${ }^{* \star * * E}$ Etlik Zübeyde Hanım Gynecology Training and Research Hospital, Clinic of Neonatal, Ankara, Turkey
}

Keywords

Autoamputation, complex ovarian cyst, neonate

\author{
Anahtar kelimeler \\ Otoamputasyon, kompleks over kisti, \\ yenidoğan \\ Received/Geliş Tarihi : 21.02 .2014 \\ Accepted/Kabul Tarihi : 21.08.2014 \\ DOI: $10.4274 /$ jcp. 66375 \\ Address for Correspondence/Yazışma Adresi: \\ Alkım Öden Akman MD, Ankara Child \\ Health and Diseases Hematology Oncology \\ Training and Research Hospital, Clinic of \\ Child Health and Diseases, Ankara, Turkey \\ Phone: +90 5437309188 \\ E-mail: alkimakman@gmail.com
}

(C) The Journal of Current Pediatrics, published by Galenos Publishing. (C) Güncel Pediatri Dergisi, Galenos Yayınevi tarafından basılmıştır.

\begin{abstract}
With the wide common use of ultrasound, ovarian cysts of the fetus and neonate are more often detected. A case series of four infant with uncommon complications of antenatal ovarian cysts were presented. In the first case; autoamputated ovarian tissue was determined and disappeared during the follow up. The second and third case went under surgery. Histopathological results were reported as a torsional autoamputated hemorrhagic necrotic tuba-ovarian cyst. Abdominal ascites was determined postnatally due to rupture of neonatal ovarian cyst in the fourth case. The treatment approaches for ovarian cysts poses a therapeutic dilemma for the pediatrician and the pediatric surgeon. It has to be decided which patient should be referred for surgical therapy and which might be treated conservatively.

\section{$\ddot{\mathbf{O z}}$}

Ultrasonun sık kullanımıyla fetal ve neonatal dönemde yenidoğan over kistleri daha sık saptanmaktadır. Bu yazıda; nadir komplikasyonlarla giden antenatal tanılı over kisti olguları sunulmuştur. Birinci olguda, otoampute over kisti saptanmış ve takibinde spontan kaybomuştur. İkinci ve üçüncü olguya cerrahi tedavi uygulanmıştır. Histopatolojik sonucu otoampute hemorajik nekrotik torsiyone tuba ovaryan kist olarak raporlanmıştır. Dördüncü olguda da, postnatal dönemde antenatal over kisti rüptürüne bağlı abdominal asit saptanmıştır. Pediatrist ve çocuk cerrahları için yenidoğan over kistlerinin tedavi yaklaşımı halen tartışmalıdır. Hangi hastada cerrahi, hangi hastada konservatif tedavi yaklaşımı yapılacağı belirlenmelidir.
\end{abstract}

\section{Introduction}

Fetal ovarian cysts are intra-abdominal structures frequently diagnosed prenatally in the third trimester, tending to present as isolated unilateral lesions in normal fetuses. With improvement of fetal ultrasound (US) imaging, prenatal diagnosis of fetal ovarian cyst is now common, in up to 1 in every 2.625 pregnancies. Most of these cysts are small and they involute spontaneously within the first few months of life. The etiology of neonatal ovarian cysts (NOC) is still unknown, although various hypotheses exist, with the most widely 
accepted hypothesis being that the fetal ovary produces them under the influence of various hormones-fetal gonadotropins, maternal estrogen and placental human chorionic gonadotropin. These cysts have their origin for the most part in the follicle epithelium; they can also be theca-lutein cysts, corpus luteum cysts or simple cysts whose origin cannot be determined. The association of fetal ovarian cysts with maternal diabetes or hypothyroidism has also been described $(1,2)$.

Cysts are classified with regard to their ultrasonographic features as simple (completely anechoic and within a thin wall) or complex (hemorrhagic cysts with a fluid-debris level, a retracting clot, septated or with solid contents-corresponding to the presence of liquid blood or an organized hematoma), and with regard to their size as small or large cysts. Spontaneous regression occurs in more than half of NOC cases in the prenatal or postnatal period (3). Ovarian torsion is the most common complication, with an incidence ranging from $38 \%$ to $55 \%$ during pregnancy (1). The ovarian torsion frequently leads to further complications such as rupture resulting in hemoperitoneum, ascites stemming from transudation, adhesion with adjacent organs resulting in urinary intestinal obstruction, calcification of cyst walls, and autoamputation of the ovary (4-6).

Four neonatal cases with uncommon complications of complex ovarian cysts are presented.

\section{Case 1}

A 28-week-gestation female fetus presented with an abdominal cystic mass in the right quadrant of abdomen measuring 40x42 $\mathrm{mm}$ on antenatal US. The baby was born with cesarean section at 37 weeks gestation with a birth weight of $2.9 \mathrm{~kg}$. Postnatally, the baby was followed with serial ultrasonography with a normal physical examination. On pelvic US, there was no viability in the right ovarian tissue and normal left ovarian tissue was intact. Hematologic and biochemical parameters (beta human chorionic gonadotropin, alpha-fetoprotein, lactate dehydrogenase) were normal. Within six months of the baby, a wandering cystic mass was visualized in the left quadrant of the abdomen and thought to be auto-amputated ovarian cyst. Abdominal Computed Tomography (CT) revealed a cystic mass with a fluid debris level and round calcification of the cyst wall (Figure 1). During the follow up, the autoamputated cystic mass was spontaneously resolved within 9 months. The baby is fifteen months old age and is still being followed asymptomatically with a normal ultrasonographic intact left ovary.

\section{Case 2}

A female baby was vaginally delivered at 39-weekgestation with a 3500 gr weight in our hospital. A cystic mass with a measurement of $35 \times 40 \mathrm{~mm}$ was noticed in the right quadrant of the abdomen on 30th week-gestation antenatal US check up. Postnatal physical examination was normal. The baby was followed asymptomatically with serial US. The displacement of the cystic mass in the abdomen was determined at 11 months of age. On the abdominal MR imaging 35x35 mm thin-walled, hyperecoic fluid debris cystic mass was placed in the left quadrant of the abdomen was determined. The cystic mass thought to be torsioned ovarian cyst but the baby was asymptomatic. Laparoscopic operation was done. Free cystic mass was observed in the abdomen during the surgery. Left ovary and the fallopian tube were normal. Histopathological result was reported as an autoamputated hemorrhagic necrotic torsioned tuba-ovarian cyst. After surgery no complication was observed.

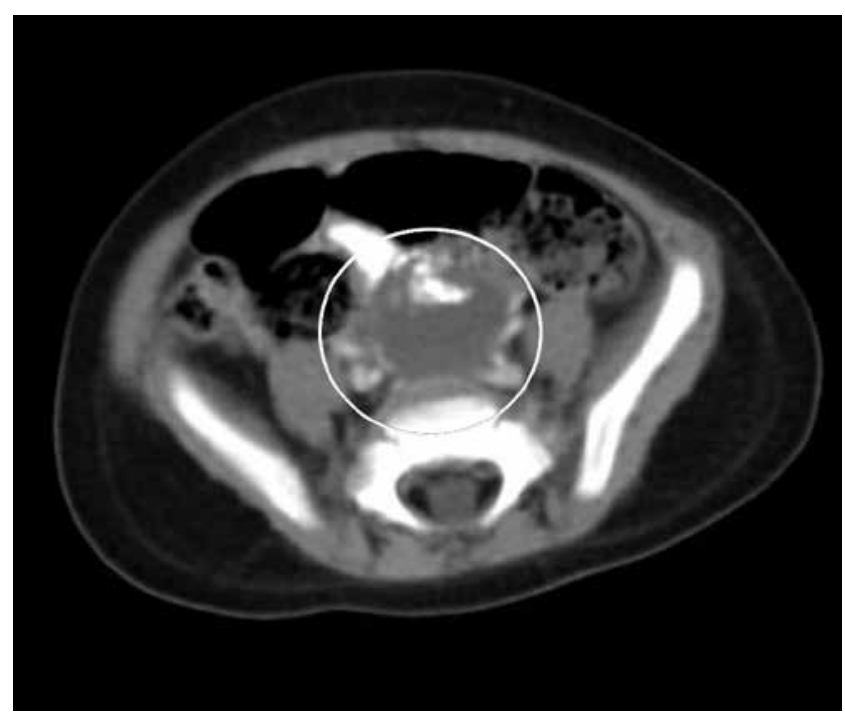

Figure 1. A cystic mass with a fluid debris level and round calcification of the cyst wall 


\section{Case 3}

In the third case; $55 \times 55 \mathrm{~mm}$ cystic mass in the abdomen was detected antenatal 32 week-gestation US. Antenatal follow-up was uneventful. Serum alpha-fetoprotein level was increased $(1240 \mathrm{mcg} /$ dl). The cystic mass had a component of solid and calcified wall with a sign of compression. Because of the risk of malignancy, laparotomy was performed in the neonatal period successfully. The histopathologic report was the same as the second case. This case is also following asymptomatically.

\section{Case 4}

The cystic mass $(35 \times 45 \mathrm{~mm})$ was noticed in the third trimester of the pregnancy. The baby was born full term, $3660 \mathrm{gr}$ weight with a cesarean section. After the delivery respiratory distress and abdominal distention was observed. A free fluid in the abdomen was seen on US. Ruptured ovarian cyst was suspected and paracentesis was done successfully. The hematologic and biochemical markers were normal and the cytology of the paracentesis material was negative. No accumulation of fluid was observed during the follow-up. The patient is very well with two healthy ovarian imaging.

\section{Discussion}

NOCs are the most frequent, prenatally diagnosed intra-abdominal cysts (7). When cysts are once detected, close ultrasonographic follow-up is necessary in order to detect possible complications and to make a differential diagnosis. Mesenteric, omental and urachal cysts, duplication anomalies, structures or anomalies leading to intestinal or urinary obstruction such as renal cysts, cystic meconium peritonitis, hydrometrocolpos, duodenal atresia, and anterior meningocele should be considered in the differential diagnosis of a cystic abdominal mass in a female fetus. Malignant tumors are rare in the neonatal period, but benign cystic teratomas are the most common ovarian tumors (3).

US play an important role in diagnosis and followup of NOC. The sonographic features of a cyst containing fluid-debris level, cyst with an echogenic nodule or with 'fish-net appearance' favours torsion (8). Also the experience of the radiologist is important in these cases.
The risk of ovarian torsion is related more to the length of the pedicle than to the size of the cyst. Ovarian torsion, rare in the postnatal period, is relatively more frequent in the intrauterine period and during birth. Antenatal percutaneous aspiration of ovarian cysts has been suggested. Aspiration of the cyst reduces its size and its contents can be investigated. Antenatal aspiration is less likely to be successful because continued hormonal stimulation which may lead to recurrence of the cyst. Aspiration of the cysts is recommended only if it is huge enough to impair spontaneous delivery or cause distention of the fetal abdomen. Thus, fetal ovarian cyst decompression, in selected cases, may preserve ovaries at risk for torsion (9). Criteria for prenatal decompression are still need to be evaluated.

Potential complications of fetal ovarian cysts include torsion with loss of ovary, rupture, hemorrhage and compression of other viscera. A rare complication of NOC is autoamputation, which presents as a wandering mass in the abdomen. There have been reported cases of autoamputated ovarian cysts within the first year of age (6). Ruptured ovarian cyst should be included in the differential diagnosis of unexplained ascites in a new born girl (10).

Pre and postnatal management of complex NOC is still controversial. Neonatal surgery in case of complex ovarian cysts allows a definite diagnosis, assessment of ovarian viability, division of any inflammatory adhesions, and removal of the cyst and detorsion of the ovary for optimal ovarian preservation in some instances. Recently, conservative management of the complex ovarian cysts has been advocated. The conservative treatment of the complex ovarian cysts is based on the fact that they can regress and this will lead to avoid unnecessary surgery and might preserve ovarian parenchyma that may be detected after disappearance of the cyst (11). Cesca et al. (12) determined that during long-term follow-up of the complex NOC, both ovaries are found to be $60 \%$ viable even at puberty. Luzzatto et al. (13) recommend postnatal conservative management of the complex cysts regardless of their size. In a recently published study, resolution of two complex pelvic masses due to autoamputated adnexa with expectant management were reported in two neonate cases (14). Surgical attitude, which is fairly widespread, should therefore be questioned. 
Long-term outcome during adolescence and adulthood after perinatal ovarian torsion, is unknown. Although results from experimental studies in animals have shown a compensatory effect from the single ovary after unilateral oophorectomy, clinical studies suggested that women with a single ovary have reduced ovarian reserve and may have a shorter reproductive life span (15).

A case series of four infant with an uncommon complications of antenatal ovarian cyst were presented. In the first case; autoamputated ovarian tissue was determined and disappeared during the follow up. The second and third case went under surgery.

With the development of US imaging, NOC are more frequently diagnosed. Pediatricians will be consulted more frequently about neonates with ovarian cysts. Fetal ovarian cysts' size and nature are considered as the most important factors for determining the treatment options. The evidence based decision making criteria should be determined for the surgery intervention. Also long term results and possible supportive treatment of single ovary should be clarified.

\section{Ethics}

Informed Consent: The ethical consent were received from the patient's family.

Peer-review: Externally peer-reviewed.

\section{Authorship Contributions}

Surgical and Medical Practices: Mithat Haliloğlu , Alkım Öden Akman, Nazile Ertürk, Ahmet Yağmur Baş, Sibel Altınbaş, Concept: Alkım Öden Akman, Nazile Ertürk, Ahmet Yağmur Baş, Design: Alkım Öden Akman, Nazile Ertürk, Data Collection or Processing: Alkım Öden Akman, Nazile Ertürk, Analysis or Interpretation: Alkım Öden Akman, Ahmet Yă̆mur Baş, Literature Search: Alkım Öden Akman, Nazile Ertürk, Writing: Alkım Öden Akman, Nazile Ertürk.

Conflict of Interest: No conflict of interest was declared by the authors.
Financial Disclosure: The authors declared that this study received no financial support.

\section{References}

1. Bryant AE, Laufer MR. Fetal ovarian cysts: Incidence, diagnosis and management. J Reprod Med 2004;49:329-37.

2. Özdilek B, Nalbantoğlu B, Donma MM, Çelik C, Paketçi C, Karasu E, ve ark. Yenidoğanda over kisti. Çocuk Dergisi 2013;13:36-9.

3. Vogtländer MF, Rijntjes-Jacobs EG, van den Hoonaard TL, Versteegh FG. Neonatal ovarian cysts. Acta Paediatr 2003;92:498-501.

4. Nussbaum AR, Sanders RC, Benator RM, Haller JA Jr, Dudgeon DL. Spontaneous resolution of neonatal ovarian cysts. AJR Am J Roentgenol 1987;148:175-6.

5. Galinier P, Carfagna L, Juricic M, Lemasson F, Moscovici J, Guitard J, et al. Fetal ovarian cysts management and ovarian prognosis: A report of 82 cases. J Pediatr Surg 2008;43:2004-9.

6. Koike Y, Inoue M, Uchida K, Kawamoto A, Yasuda H, Okugawa $\mathrm{Y}$, et al. Ovarian autoamputation in a neonate: A case report with literature review. Pediatr Surg Int 2009;25:655-8.

7. Mortellaro VE, Fike FB, Sharp SW, St Peter SD. Operative findings in antenatal abdominal masses of unknown etiology in females. J Surg Res 2012;177:137-8.

8. Chinchure D, Ong CL, Loh AH, Rajadurai VS. Neonatal ovarian cysts: Role of sonography in diagnosing torsion. Ann Acad Med Singapore 2011;40:291-5.

9. Heling KS, Chaoui R, Kirchmair F, Stadie S, Bollmann R. Fetal ovarian cysts: Prenatal diagnosis, management and postnatal outcome. Ultrasound Obstet Gynecol 2002;20:47-50.

10. Vyas ID, Variend S, Dickson JA. Ruptured ovarian cyst as a cause of ascites in a newborn infant. Z Kinderchir 1984;39:143-4.

11. Monnery-Noché ME, Auber F, Jouannic JM, Bénifla JL, Carbonne B, Dommergues M, et al. Fetal and neonatal ovarian cysts: Is surgery indicated? Prenat Diagn 2008;28:15-20.

12. Cesca E, Midrio P, Boscolo-Berto R, Snijders D, Salvador L, D'Antona Det al. Conservative treatment for complex neonatal ovarian cysts: A long-term follow-up analysis. J Pediatr Surg 2013;48:510-5.

13. Luzzatto C, Midrio P, Toffolutti T, Suma V. Neonatal ovarian cysts: Management and follow-up. Pediatr Surg Int 2000;16:569.

14. Trotman GE, Zamora M, Gomez-Lobo V. Non-surgical management of the auto-amputated adnexa in the neonate: A report on two cases. J Pediatr Adolesc Gynecol 2014;27:107-10.

15. Lass A, Brinsden P. The role of ovarian volume in reproductive medicine. Hum Reprod Update 1999;5:256-66. 